\title{
Association between polymorphism in CDKN2B-AS1 gene and its interaction with smoking on the risk of lung cancer in a Chinese population
}

\author{
Xiaoting $\mathrm{Lv}^{1,2}$, Zhigang Cui ${ }^{3}$, Hang $\mathrm{Li}^{1,2}$, Juan $\mathrm{Li}^{1,2}$, Zitai Yang ${ }^{1,2}$, Yanhong Bi ${ }^{1,2}$, Min Gao ${ }^{1,2}$, Ziwei Zhang ${ }^{1,2}$,
} Shengli Wang ${ }^{1,2}$, Baosen Zhou ${ }^{1,2}$ and Zhihua Yin ${ }^{1,2^{*}}$ (i)

\begin{abstract}
Background: Long non-coding RNAs became the hot spots in the carcinogenesis of various tumors. This casecontrol study evaluated the association between the rs2151280 in IncRNA CDKN2B-AS1 and lung cancer risk.

Methods: This study included 507 lung cancer patients and 542 healthy individuals. Odds ratios and their 95\% confidence intervals were calculated by unconditional logistic regression analysis to evaluate the association between the rs2151280 and lung cancer risk.

Results: Compared with individuals carrying $\Pi$ genotype, individuals carrying CC genotype of rs 2151280 had a decreased risk of lung cancer $(\mathrm{OR}=0.640,95 \% \mathrm{Cl}=0.421-0.972, P=0.036)$. In the recessive model, rs $2151280 \mathrm{CC}$ genotype was observed to reduce the risk of lung cancer $(O R=0.684)$. C allele was associated with non-small cell lung cancer risk $(\mathrm{OR}=0.674)$. The rs 2151280 was significantly associated with lung adenocarcinoma risk (CCvs $T$ : OR $=0.567,95 \% \mathrm{Cl}=0.333-0.965, P=0.037 ; \mathrm{CCVsTC}+\mathrm{T}: \mathrm{OR}=0.543,95 \% \mathrm{Cl} 0.330-0.893, P=0.016$, respectively). However, there was no significant association between rs 2151280 and lung squamous cell carcinoma risk in five models. The quantitative analysis suggested that there were no significant interactions of rs 2151280 with smoking exposure to lung cancer susceptibility.
\end{abstract}

Conclusions: This hospital-based case-control study suggested that CDKN2B-AS1 rs2151280 T>C was associated with the risk of lung cancer.

Keywords: Interaction, Lung cancer, IncRNA, Single nucleotide polymorphism

\section{Introduction}

Lung cancer is a complex and malignant cancer with the high morbidity. Both environmental and genetic factors were acknowledged to the most important pathogenic factors for lung cancer. Lung cancer is divided into non-small cell lung cancer (NSCLC) and small cell lung cancer. NSCLC includes four major types: adenocarcinoma, squamous cell carcinoma, large cell carcinoma, and adenosquamous carcinoma.

\footnotetext{
* Correspondence: zhyin@cmu.edu.cn

'Department of Epidemiology, School of Public Health, China Medical University, Shenyang 110122, People's Republic of China

${ }^{2}$ Key Laboratory of Cancer Etiology and Intervention, University of Liaoning

Province, Shenyang 110122, People's Republic of China

Full list of author information is available at the end of the article
}

Age, lifestyle [1], genetic , endocrine [2], occupational exposure $[3,4]$, and other environmental factors [5] play important roles in lung cancer. In the past years, studies had shown that smoking was the strongest environmental risk factor for the occurrence and development of lung cancer. However, it was also reported that $25 \%$ of lung cancer patients were non-smokers. It suggested that genetic risk factor might play an important role in lung cancer. At the same time, some molecular epidemiological studies had suggested that the interaction between genetic and environmental factors might affect the incidence and development of lung cancer. However,

(c) The Author(s). 2019 Open Access This article is distributed under the terms of the Creative Commons Attribution 4.0 International License (http://creativecommons.org/licenses/by/4.0/), which permits unrestricted use, distribution, and 
the exact etiology and pathogenesis of lung cancer remained obscure.

With the in-depth study of high-throughput technologies, many genome-wide association studies (GWASs) had found the correlation between long non-coding RNAs (lncRNAs) and multiple cancers. LncRNAs, a class of non-coding RNA, ranging from 200 to $100 \mathrm{kbp}$ in length, included non-protein coding transcripts [6]. While the lncRNAs were regarded as the "transcribed noise" in the early years, increasing evidence had shown that lncRNAs played key roles in biological processes. As regulators in cellular processes, lncRNAs could inhibit cell growth [7] and influence cell differentiation [8] and cell metastasis [9]. LncRNAs were known to play critical roles in multiple cancers by regulating multiple molecular regulation [10]. $C D K N 2 B-A S 1$ is an lncRNA $(3.8 \mathrm{~kb})$ transcribed from the INK4B-ARF-INK4A gene, locating on human chromosome 9p21 [11, 12]. GWAS had shown that SNPs in this region (9p21) were associated with many diseases, including cancers $[13,14]$. Many studies had shown that the oncogenic properties of CDKN2B-AS1 was existed in multiple carcinomas (thyroid cancer [15], gastric cancer [16], lung cancer [17, 18], and so on). Compared with normal controls, the overexpression of $C D K N 2 B-A S 1$ was obviously found in NSCLC tissues and serum samples [19]. The expression level of $C D K N 2 B-A S 1$ was higher in human non-small cell lung cancer than normal diploid fetal lung fibroblasts. The proliferation of H1299 cells were regulated by lncRNA CDKN2B-AS1 [20]. The c-Myc was a closely-watched transcription factor which was overexpressed in NSCLC [21]. The c-Myc could directly transactivate $C D K N 2 B-A S 1$, and $C D K N 2 B-A S 1$ could promote the proliferation of NSCLC cells [22].

A meta-analysis of 16 GWASs identified a novel disease locus for squamous cell carcinoma at 9p21. The result also found that $9 \mathrm{p} 21.3$ variants in the region of $C D K N 2 B-A S 1$ were associated with squamous cell lung cancer [23]. So the functional genetic variations in the lncRNA CDKN2B-AS1 might contribute to the susceptibility of lung cancer. rs2151280 was located within the lncRNA CDKN2B$A S 1$ at 9p21.3. Because rs2151280 might affect the expression of CDKN2B-AS1 [24], and CDKN2B-AS1 expression might affect the susceptibility of lung cancer, we suspected that rs2151280 might affect the susceptibility of lung cancer. Emerging evidence demonstrated that rs2151280 was related to various kinds of malignant tumors, which indirectly confirmed the importance of rs 2151280 in cancer susceptibility. rs2151280 was initially discovered by a GWAS research on the correlation between rs2151280 and the risk of basal cell carcinoma, and the results showed that rs2151280 was related to the risk of basal cell carcinoma (BCC) [25]. The high expression of $C D K N 2 B-A S 1$ and the low expression of p14ARF were associated with rs2151280 TT variant in peripheral blood mononuclear cells (PBMCs) [26]. Molecular epidemiological studies had shown that rs2151280 was associated with various cancer risks (BCC [25] and plexiform neurofibromas (PNF) [24]). The association between $C D K N 2 B-A S 1$ rs2151280 and esophageal squamous cell carcinoma (ESCC) was not found in the study [27]. The relationship between CDKN2B-AS1 rs2151280 and the risk of lung cancer was still unclear in the world.

Because the association between CDKN2B-AS1 rs2151280 and lung cancer was undefined, our research had some innovation in investigating the association between CDKN2B-AS1 rs2151280 and lung cancer risk. Therefore, we decided to further explore this SNP by supporting the above evidence in 507 lung cancer patients and 542 cancer-free controls. And we also evaluated the interaction of rs2151280 with smoking status on the risk of lung cancer in the case-control study. As far as we know, this was the first time to evaluate the effect of rs2151280 in lncRNA CDKN2B-AS1 on lung cancer risk.

\section{Materials and methods Study subjects}

Our study was an ongoing hospital-based case control study. Quanto1.2.4 statistical software was used to calculate the sample size. Since we only found the incidence of lung cancer, we calculated the sample size according to the incidence of lung cancer. Lung cancer is divided into non-small cell lung cancer and small cell lung cancer. NSCLC includes four major types: adenocarcinoma, squamous cell carcinoma, large cell carcinoma, and adenosquamous carcinoma. We wanted to further explore the relationship between the risk of each type of pathology and rs2151280. So we performed pathological type analysis based on the collected patient information. We recruited 507 Han Chinese lung cancer patients and 542 Han Chinese healthy individuals in Shenyang City, located in northeast China. For excluding population admixture effects, we investigated the ethnicity of the participants' parents for three generations. We perform a power calculation. The power was more than 0.88 . All the cases were (1) newly diagnosed as lung cancer patients, (2) never accepted treatments, and (3) without cancer history or metastatic cancer. The healthy individuals were (1) selected in the same period in the same hospitals and 
Table 1 Distribution of demographic variables in lung cancer and controls

\begin{tabular}{|c|c|c|c|}
\hline Risk factor & $\begin{array}{l}\text { Lung cancer } \\
(N=507)\end{array}$ & $\begin{array}{l}\text { Controls } \\
(N=542)\end{array}$ & $P$ \\
\hline Age (mean \pm SD) & $59.20 \pm 9.872$ & $58.10 \pm 11.504$ & 0.096 \\
\hline \multicolumn{4}{|l|}{ Gender } \\
\hline Male & 255 (50.3\%) & $262(48.3 \%)$ & \multirow[t]{2}{*}{0.527} \\
\hline Female & 252 (49.7\%) & $280(51.7 \%)$ & \\
\hline \multicolumn{4}{|l|}{ Smoking status } \\
\hline Ever & 217 (42.8\%) & 66 (12.2\%) & \multirow[t]{2}{*}{$<0.001$} \\
\hline Never & 290 (57.2\%) & $476(87.8 \%)$ & \\
\hline \multicolumn{4}{|l|}{ Stage } \\
\hline $\mathrm{l}, \mathrm{II}$ & 93 (18.3\%) & & \\
\hline III & $146(28.8 \%)$ & & \\
\hline IV & 84 (16.6\%) & & \\
\hline Missing & $184(36.3 \%)$ & & \\
\hline \multicolumn{4}{|l|}{ Pathological type } \\
\hline$A D$ & 248 (48.92\%) & & \\
\hline SQ & 125 (24.65\%) & & \\
\hline SCC & $90(17.75 \%)$ & & \\
\hline Else & 44 (8.68\%) & & \\
\hline
\end{tabular}

$A D$ lung adenocarcinoma, SQ lung squamous cell carcinoma, SCC small cell lung cancer

(2) matched age and gender during the epidemiological survey. All enrolled subjects signed the informed consent forms and the institutional review board of China Medical University approved this study. Ten-milliliter venous blood sample collected from all enrolled subjects to detect the SNP. Phenol- chloroform method was used to isolate genomic DNA sample from venous blood. The rs2151280 was genotyped by 7500 Fast Real-time PCR system. In each genotyping process, blank controls were needed. The investigators randomly selected 10\% samples to genotype twice for quality control, and the results were concordant with the duplicate samples.

\section{Statistical analysis}

Student's $t$ test and $\chi^{2}$ test were calculated to analyze the difference in continuous and categorical variables between cases and healthy individuals, respectively. The goodness-of-fit $\mathrm{X} 2$ test was used to examine the Hardy-Weinberg equilibrium (HWE) of rs2151280. We calculated the odds ratios (ORs) with their $95 \%$ confidence intervals (CIs) by unconditional logistic regression to evaluate the relationship between rs2151280 and lung cancer risk. The interaction of smoking status and rs2151280 on risk of lung cancer was evaluated by logistic regression on additive model and multiplicative model. The criterion of statistical significance was defined as $P<0.05$, and all of the statistical tests were two-sided in this study. All the statistical analyses were calculated by SPSS software.

\section{Results}

The demographic of 507 lung cancer cases and 542 healthy individuals was shown in Table 1 . In terms of age, cases and controls seemed to be exactly matched $(P=0.096)$. There were no statistically significant differences in the proportion of sex status between the lung cancer case group (50.3\% males and 49.7\%

Table 2 The association of the rs 2151280 with lung cancer risk and non-small cell lung cancer

\begin{tabular}{|c|c|c|c|c|c|c|c|c|c|c|c|}
\hline \multirow[t]{2}{*}{ Genotyping } & \multirow[b]{2}{*}{ Controls (\%) } & \multicolumn{2}{|c|}{ Lung cancer } & \multirow[b]{2}{*}{$P$ value } & \multirow[b]{2}{*}{$\mathrm{OR}^{\mathrm{a}}(95 \% \mathrm{Cl})$} & \multirow[b]{2}{*}{$P$ a value } & \multicolumn{2}{|c|}{$\begin{array}{l}\text { Non-small-cell lung } \\
\text { cancer }\end{array}$} & \multirow[b]{2}{*}{$P$ value } & \multirow[b]{2}{*}{$\mathrm{OR}^{\mathrm{a}}(95 \% \mathrm{Cl})$} & \multirow[b]{2}{*}{$P$ a value } \\
\hline & & Cases (\%) & OR $(95 \% \mathrm{Cl})$ & & & & Cases (\%) & OR $(95 \% \mathrm{Cl})$ & & & \\
\hline TT & $203(37.5)$ & $207(40.8)$ & 1.00 (ref) & & & & $153(38.9)$ & 1.00 (ref) & & & \\
\hline TC & $255(47.0)$ & $244(48.1)$ & $\begin{array}{l}0.938 \\
(0.723-1.219)\end{array}$ & 0.633 & $\begin{array}{l}0.976 \\
(0.737-1.292)\end{array}$ & 0.865 & $196(49.9)$ & $\begin{array}{l}1.020 \\
(0.770-1.350)\end{array}$ & 0.891 & $\begin{array}{l}1.072 \\
(0.791-1.453)\end{array}$ & 0.654 \\
\hline CC & 84 (15.5) & $56(11.0)$ & $\begin{array}{l}0.654 \\
(0.443-0.965)\end{array}$ & 0.033 & $\begin{array}{l}0.640 \\
(0.421-0.972)\end{array}$ & 0.036 & $44(11.2)$ & $\begin{array}{l}0.695 \\
(0.456-1.059)\end{array}$ & 0.090 & $\begin{array}{l}0.698 \\
(0.444-1.098)\end{array}$ & 0.120 \\
\hline $\mathrm{CC}+\mathrm{TC}$ vs TT & & & $\begin{array}{l}0.868 \\
(0.677-1.112)\end{array}$ & 0.263 & $\begin{array}{l}0.890 \\
(0.682-1.162)\end{array}$ & 0.392 & & $\begin{array}{l}0.939 \\
(0.719-1.227)\end{array}$ & 0.646 & $\begin{array}{l}0.976 \\
(0.731-1.304)\end{array}$ & 0.871 \\
\hline$C C$ vs TC+TT & & & $\begin{array}{l}0.677 \\
(0.471-0.973)\end{array}$ & 0.035 & $\begin{array}{l}0.648 \\
(0.439-0.957)\end{array}$ & 0.029 & & $\begin{array}{l}0.687 \\
(0.465-1.016)\end{array}$ & 0.060 & $\begin{array}{l}0.672 \\
(0.441-1.022)\end{array}$ & 0.063 \\
\hline T allele & $661(61.0)$ & $658(64.9)$ & 1.00 (ref) & & & & $502(63.9)$ & 1.00 (ref) & & & \\
\hline C allele & $423(39.0)$ & $356(35.1)$ & $\begin{array}{l}0.845 \\
(0.708-1.010)\end{array}$ & 0.064 & & & $284(36.1)$ & $\begin{array}{l}0.674 \\
(0.560-0.812)\end{array}$ & 0.001 & & \\
\hline
\end{tabular}


Table 3 The association of the rs2151280 with lung adenocarcinoma risk and lung squamous cell carcinoma risk

\begin{tabular}{|c|c|c|c|c|c|c|c|c|c|c|c|}
\hline \multicolumn{2}{|c|}{ Genotyping } & \multicolumn{2}{|c|}{ Lung adenocarcinoma } & \multirow[b]{2}{*}{$P$ value } & \multirow[b]{2}{*}{ ORa $(95 \% \mathrm{Cl})$} & \multirow[b]{2}{*}{$P$ a value } & \multicolumn{2}{|c|}{ Lung squamous cell carcinoma } & \multirow[b]{2}{*}{$P$ value } & \multirow[b]{2}{*}{ ORa $(95 \% C l)$} & \multirow[b]{2}{*}{ Pa value } \\
\hline & Controls (\%) & Cases (\%) & OR $(95 \% \mathrm{Cl})$ & & & & Cases (\%) & OR $(95 \% \mathrm{Cl})$ & & & \\
\hline$\pi$ & $203(37.5)$ & $98(39.5)$ & 1.00 (ref) & & & & & 1.00 (ref) & & & \\
\hline TC & $255(47.0)$ & $126(50.8)$ & $\begin{array}{l}1.024 \\
(0.742-1.412)\end{array}$ & 0.887 & $\begin{array}{l}1.082 \\
(0.773-1.513)\end{array}$ & 0.646 & $43(34.4)$ & $\begin{array}{l}1.203 \\
(0.785-1.845)\end{array}$ & 0.396 & $\begin{array}{l}1.530 \\
(0.893-2.621)\end{array}$ & 0.122 \\
\hline CC & $84(15.5)$ & $24(9.7)$ & $\begin{array}{l}0.592 \\
(0.354-0.989)\end{array}$ & 0.045 & $\begin{array}{l}0.567 \\
(0.333-0.965)\end{array}$ & 0.037 & $65(52.0)$ & $\begin{array}{l}0.955 \\
(0.516-1.770)\end{array}$ & 0.885 & $\begin{array}{l}1.343 \\
(0.615-2.932)\end{array}$ & 0.459 \\
\hline \multicolumn{2}{|c|}{$\mathrm{CC}+\mathrm{TC}$ vs TT } & & $\begin{array}{l}0.917 \\
(0.673-1.248)\end{array}$ & 0.580 & $\begin{array}{l}0.948 \\
(0.688-1.306)\end{array}$ & 0.743 & $17(13.6)$ & $\begin{array}{l}1.142 \\
(0.759-1.717)\end{array}$ & 0.524 & $\begin{array}{l}1.487 \\
(0.889-2.488)\end{array}$ & 0.130 \\
\hline \multicolumn{2}{|c|}{ CC vs TC+TT } & & $\begin{array}{l}0.584 \\
(0.361-0.945)\end{array}$ & 0.028 & $\begin{array}{l}0.543 \\
(0.330-0.893)\end{array}$ & 0.016 & & $\begin{array}{l}0.858 \\
(0.489-1.505)\end{array}$ & 0.594 & $\begin{array}{l}1.053 \\
(0.518-2.143)\end{array}$ & 0.886 \\
\hline T allele & $661(61.0)$ & $322(64.9)$ & 1.00 (ref) & & & & $151(60.4)$ & 1.00 (ref) & & & \\
\hline C allele & $423(39.0)$ & $174(35.1)$ & $\begin{array}{l}0.844 \\
(0.677-1.053)\end{array}$ & 0.134 & & & 99 (39.6) & $\begin{array}{l}1.025 \\
(0.773-1.357)\end{array}$ & 0.866 & & \\
\hline
\end{tabular}

$O R$ odds ratio, $\mathrm{Cl}$ confidence interval

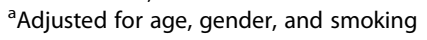

Table 4 The association of the rs 2151280 with lung cancer risks and NSCLC in female and male population

\begin{tabular}{|c|c|c|c|c|c|c|c|c|c|c|c|}
\hline \multicolumn{2}{|c|}{ Genotyping } & \multicolumn{2}{|c|}{ Lung cancer } & \multirow[b]{2}{*}{$P$ value } & \multirow[b]{2}{*}{ ORa $(95 \% \mathrm{Cl})$} & \multirow[b]{2}{*}{ Pa value } & \multicolumn{3}{|c|}{ Non-small-cell lung cancer } & \multirow[b]{2}{*}{ ORa $(95 \% \mathrm{Cl})$} & \multirow[b]{2}{*}{ Pa value } \\
\hline & Controls (\%) & Cases (\%) & OR $(95 \% \mathrm{Cl})$ & & & & Cases (\%) & OR (95\%Cl) & $P$ value & & \\
\hline \multicolumn{12}{|l|}{ Female } \\
\hline$\pi$ & $104(37.1)$ & $102(40.5)$ & 1.00 (ref) & & & & $73(37.8)$ & 1.00 (ref) & & & \\
\hline TC & $123(43.9)$ & $122(48.4)$ & $\begin{array}{l}1.011 \\
(0.698-1.465)\end{array}$ & 0.953 & $\begin{array}{l}0.984 \\
(0.676-1.434)\end{array}$ & 0.935 & $97(50.3)$ & $\begin{array}{l}1.124 \\
(0.753-1.677)\end{array}$ & 0.569 & $\begin{array}{l}1.109 \\
(0.740-1.661)\end{array}$ & 0.616 \\
\hline CC & $53(18.9)$ & $28(11.1)$ & $\begin{array}{l}0.539 \\
(0.316-0.918)\end{array}$ & 0.023 & $\begin{array}{l}0.533 \\
(0.310-0.916)\end{array}$ & 0.023 & $23(11.9)$ & $\begin{array}{l}0.618 \\
(0.348-1.097)\end{array}$ & 0.100 & $\begin{array}{l}0.606 \\
(0.339-1.081)\end{array}$ & 0.090 \\
\hline \multicolumn{2}{|c|}{$\mathrm{CC}+\mathrm{TC}$ vs TT } & & $\begin{array}{l}0.869 \\
(0.613-1.232)\end{array}$ & 0.431 & $\begin{array}{l}0.850 \\
(0.596-1.211)\end{array}$ & 0.368 & & $\begin{array}{l}0.971 \\
(0.665-1.419)\end{array}$ & 0.880 & $\begin{array}{l}0.957 \\
(0.653-1.402)\end{array}$ & 0.822 \\
\hline \multicolumn{2}{|c|}{ CC vs TC+TT } & & $\begin{array}{l}0.535 \\
(0.327-0.877)\end{array}$ & 0.013 & $\begin{array}{l}0.538 \\
(0.326-0.888)\end{array}$ & 0.015 & & $\begin{array}{l}0.579 \\
(0.342-0.983)\end{array}$ & 0.043 & $\begin{array}{l}0.572 \\
(0.335-0.975)\end{array}$ & 0.040 \\
\hline T allele & $331(59.1)$ & $326(64.7)$ & 1.00 (ref) & & & & $243(63.0)$ & 1.00 (ref) & & & \\
\hline C allele & $229(40.9)$ & $178(35.3)$ & $\begin{array}{l}0.789 \\
(0.616-1.012)\end{array}$ & 0.062 & & & $143(37.0)$ & $\begin{array}{l}0.851 \\
(0.652-1.110)\end{array}$ & 0.234 & & \\
\hline \multicolumn{12}{|l|}{ Male } \\
\hline$\pi$ & $99(37.8)$ & $105(41.2)$ & 1.00 (ref) & & & & & 1.00 (ref) & & & \\
\hline TC & $132(50.4)$ & $122(47.8)$ & $\begin{array}{l}0.871 \\
(0.603-1.260)\end{array}$ & 0.464 & $\begin{array}{l}0.929 \\
(0.570-1.515)\end{array}$ & 0.769 & $80(40.0)$ & $\begin{array}{l}0.928 \\
(0.626-1.375)\end{array}$ & 0.710 & $\begin{array}{l}1.078 \\
(0.624-1.862)\end{array}$ & 0.788 \\
\hline CC & $31(11.8)$ & $28(11.0)$ & $\begin{array}{l}0.852 \\
(0.477-1.521)\end{array}$ & 0.587 & $\begin{array}{l}0.724 \\
(0.336-1.558)\end{array}$ & 0.408 & 99 (49.5) & $\begin{array}{l}0.838 \\
(0.448-1.570)\end{array}$ & 0.582 & $\begin{array}{l}0.743 \\
(0.315-1.752)\end{array}$ & 0.497 \\
\hline \multicolumn{2}{|c|}{$\mathrm{CC}+\mathrm{TC}$ vs TT } & & $0.868(0.610-1.235)$ & 0.431 & $\begin{array}{l}0.886 \\
(0.555-1.4130)\end{array}$ & 0.611 & $21(10.5)$ & $\begin{array}{l}0.911 \\
(0.625-1.329)\end{array}$ & 0.628 & $\begin{array}{l}1.004 \\
(0.596-1.692)\end{array}$ & 0.989 \\
\hline \multicolumn{2}{|c|}{ CC vs TC+TT } & & $\begin{array}{l}0.919 \\
(0.534-1.582)\end{array}$ & 0.761 & $\begin{array}{l}0.753 \\
(0.367-1.545)\end{array}$ & 0.440 & & $\begin{array}{l}0.874 \\
(0.486-1.573)\end{array}$ & 0.654 & $\begin{array}{l}0.713 \\
(0.320-1.590)\end{array}$ & 0.408 \\
\hline T allele & $330(63.0)$ & $332(65.1)$ & 1.00 (ref) & & & & $259(64.8)$ & 1.00 (ref) & & & \\
\hline C allele & $194(37.0)$ & 178 (34.9) & $\begin{array}{l}0.912 \\
(0.707-1.176)\end{array}$ & 0.477 & & & $141(35.2)$ & $\begin{array}{l}0.926 \\
(0.706-1.214)\end{array}$ & 0.579 & & \\
\hline
\end{tabular}


females) and the control group (48.3\% males and $51.7 \%$ females). As expected, the distribution of smoking status was significantly different in lung cancer cases and healthy controls $(P<0.001)$. Lung cancer cases included 248 adenocarcinomas, 125 squamous cell carcinomas, 90 small cell carcinomas, and 44 other types. The observed genotype frequencies for rs2151280 were in agreement with Hardy-Weinberg equilibrium. We wanted to further explore the relationship between the risk of each type of pathology and rs2151280. So, we performed pathological type analysis based on the collected patient information.

The association between rs2151280 and lung cancer risk was shown in Table 2. Compared with individuals carrying TT genotype, individuals with CC genotype of rs 2151280 had a lower lung cancer risk $(\mathrm{OR}=0.654,95 \% \mathrm{CI}=0.443-0.965, P=0.033)$. After adjusting for age, gender and smoking status risk factors, this association remained significant (OR $=0.640,95 \% \mathrm{CI}=0.421-0.972, P=0.036)$. In the recessive model, individuals carrying variant homozygote CC genotypes were associated with a significantly lower risk of lung cancer compared with individuals carrying heterozygote $\mathrm{TC}$ and TT genotype (adjusted OR $=0.648,95 \% \mathrm{CI}=0.439-0.957, P$ $=0.029$ ). In allele comparison, the $C$ allele was associated with a lower risk of non-small-cell lung cancer $(\mathrm{OR}=0.674,95 \% \mathrm{CI}=0.560-0.812, P<0.001)$ in Table 2. The associations of rs2151280 with lung adenocarcinoma (AD) and lung squamous cell carcinoma (SQ) were shown in Table 3 . The statistically significant association was found in AD but not in SQ. Individuals with CC genotype had a 0.567 -fold decreased risk of $\mathrm{AD}$ than those carrying TT genotype $(95 \% \mathrm{CI}=0.333-0.965, P=0.037)$. In the recessive model, individuals with $\mathrm{CC}$ genotype had a 0.543 -fold decreased risk of AD than those carrying TT genotype or TC genotype $(95 \% \mathrm{CI}=0.330-0.893$, $P=0.016)$. However, there was no significant association between rs2151280 and the risk of SQ in the five models. We performed the stratification analyses to further estimate the association between rs2151280 and risk of lung cancer. In the subgroup analysis by gender, there was a significant correlation between rs2151280 and lung cancer risk in female (Table 4). Compared with TT genotype, variant CC genotype of 2151280 was associated with lower risk of lung cancer (adjusted OR $=0.533,95 \% \mathrm{CI}=$ $0.310-0.916, P=0.023)$. Compared with TT genotype and TC genotype, variant CC genotype was associated with lower risk of lung cancer and NSCLC (adjusted OR were 0.538 and 0.572, 95\% CI were $0.326-0.888$, and $0.335-0.975, P$ were 0.015 and 0.040 , respectively).
However, in the subgroup of age, we failed to find any statistically significant associations between rs2151280 and the risk of lung cancer and NSCLC (Table 5).

In the subgroup of smoking, we found the significant association among rs2151280 with the risk of lung cancer and NSCLC in the individuals who had never exposed to smoking (Table 6). Carriers of the rs2151280 CC genotype had a lower lung cancer risk than carriers with TT genotype (adjusted OR $=0.518$, $95 \% \mathrm{CI}=0.316-0.851, P=0.009)$. Individuals carrying variant homozygote $\mathrm{CC}$ genotype had decreased risk of lung cancer by 0.561 -fold (adjusted OR $=0.561$, $95 \% \mathrm{CI}=0.354-0.891, P=0.014)$ compared individuals carrying with heterozygote TC and TT genotype. CDKN2B-AS1 rs2151280 was significantly associated with the risk of NSCLC (CC vs TT: OR $=0.572$, 95\%CI $=0.334-0.980, P=0.042$; CCvsTC+TT: $\mathrm{OR}=$ $0.587,95 \% \mathrm{CI}=0.356-0.968, P=0.037$, respectively). Tables 7, 8, 9 had shown the interaction between rs2151280 and smoking exposure on the susceptibility of lung cancer, NSCLC, AD, and SQ on additive interaction. Compared to individuals with $\mathrm{CC}$ genotype and never exposure to smoking, individuals with TC/TT genotype and never smoking had the increased risk of lung cancer and lung adenocarcinoma (adjusted OR $=1.659,95 \% \mathrm{CI}=1.056-2.606, P=$ 0.028; $\mathrm{OR}=1.814,95 \% \mathrm{CI}=1.042-3.156, P=0.035$, respectively). Compared to individuals with $\mathrm{CC}$ genotype and never exposure to smoking, individuals with TC/TT genotype and ever smoking had the increased risk of lung cancer and NSCLC. At the same time, the same results existed in $\mathrm{AD}$ and $\mathrm{SQ}$ (adjusted $\mathrm{OR}$ $=7.403,95 \% \mathrm{CI}=3.815-14.366, \mathrm{OR}=12.139,95 \% \mathrm{CI}$ $=4.827-30.526$, respectively). However, the results of quantitative analyses indicated that there were no significant (Table 9). There were three measures [relative excess risk due to interaction (RERI), attributable proportion due to interaction (AP), and synergy index (S)] with their 95\% CI were used to show the relationship. The criterion of these three measures was just as our previous study [28]. Due to the $P$ value was more than 0.05 , the results of multiplicative interaction indicated that there were no association between rs2151280 risk genotypes with smoking exposure and lung cancer risk.

\section{Discussion}

Lung cancer is one of the most common malignancies, with higher morbidity and higher mortality in the world in the 21st century [29,30]. According to reports, the crude incidence of lung cancer in developing countries is increasing rapidly. Data was recorded by the International Agency for Research on 
Table 5 Stratified analyses of the rs2151280 with lung cancer risk and NSCLC by age

\begin{tabular}{|c|c|c|c|c|c|c|c|c|c|c|c|}
\hline \multicolumn{2}{|c|}{ Genotyping } & \multicolumn{2}{|c|}{ Lung cancer } & \multirow[b]{2}{*}{$P$ value } & \multirow[b]{2}{*}{ ORa $(95 \% C l)$} & \multirow[b]{2}{*}{$P a$ value } & \multicolumn{2}{|c|}{ Non-small-cell lung cancer } & \multirow[b]{2}{*}{$P$ value } & \multirow[b]{2}{*}{ ORa $(95 \% C l)$} & \multirow[b]{2}{*}{$P$ a value } \\
\hline & Controls (\%) & Cases (\%) & OR $(95 \% \mathrm{Cl})$ & & & & Cases (\%) & OR $(95 \% \mathrm{Cl})$ & & & \\
\hline \multicolumn{12}{|l|}{$>60$} \\
\hline Tा & $95(36.8)$ & $106(40.9)$ & 1.00 (ref) & & & & $83(38.1)$ & 1.00 (ref) & & & \\
\hline TC & $117(45.3)$ & $123(47.5)$ & $\begin{array}{l}0.942 \\
(0.647-1.371)\end{array}$ & 0.756 & $\begin{array}{l}0.922 \\
(0.617-1.380)\end{array}$ & 0.695 & $110(50.5)$ & $\begin{array}{l}1.076 \\
(0.726-1.594)\end{array}$ & 0.715 & $\begin{array}{l}1.054 \\
(0.690-1.611)\end{array}$ & 0.807 \\
\hline CC & $46(17.8)$ & $30(11.6)$ & $\begin{array}{l}0.584 \\
(0.324-1.000)\end{array}$ & 0.050 & $\begin{array}{l}0.622 \\
(0.350-1.108)\end{array}$ & 0.107 & $25(11.5)$ & $\begin{array}{l}0.622 \\
(0.352-1.099)\end{array}$ & 0.102 & $\begin{array}{l}0.660 \\
(0.358-1.218)\end{array}$ & 0.184 \\
\hline \multicolumn{2}{|c|}{ CC+TC vs TT } & & $\begin{array}{l}0.841 \\
(0.590-1.199)\end{array}$ & 0.339 & $\begin{array}{l}0.840 \\
(0.574-1.229)\end{array}$ & 0.369 & & $\begin{array}{l}0.948 \\
(0.653-1.376)\end{array}$ & 0.779 & $\begin{array}{l}0.946 \\
(0.633-1.414)\end{array}$ & 0.786 \\
\hline \multicolumn{2}{|c|}{ CC vs TC+TT } & & $\begin{array}{l}0.604 \\
(0.368-0.992)\end{array}$ & 0.046 & $\begin{array}{l}0.65 \\
(0.381-1.109)\end{array}$ & 0.114 & & $\begin{array}{l}0.597 \\
(0.353-1.009)\end{array}$ & 0.054 & $\begin{array}{l}0.641 \\
(0.365-1.128)\end{array}$ & 0.123 \\
\hline T allele & $307(59.5)$ & $335(64.7)$ & 1.00 (ref) & & & & $276(63.3)$ & 1.00 (ref) & & & \\
\hline$C$ allele & $209(40.5)$ & $183(35.3)$ & $\begin{array}{l}0.802 \\
(0.624-1.032)\end{array}$ & 0.086 & & & $160(36.7)$ & $\begin{array}{l}0.852 \\
(0.655-1.107)\end{array}$ & 0.230 & & \\
\hline \multicolumn{12}{|l|}{$\leq 60$} \\
\hline Tा & $108(38.0)$ & $101(40.7)$ & 1.00 (ref) & & & & $70(40.0)$ & 1.00 (ref) & & & \\
\hline TC & $138(48.6)$ & $121(48.8)$ & $\begin{array}{l}0.938 \\
(0.651-1.351)\end{array}$ & 0.729 & $\begin{array}{l}1.079 \\
(0.717-1.622)\end{array}$ & 0.716 & $86(49.1)$ & $\begin{array}{l}0.961 \\
(0.642-1.440)\end{array}$ & 0.849 & $\begin{array}{l}1.151 \\
(0.730-1.815)\end{array}$ & 0.544 \\
\hline CC & $38(13.4)$ & $26(10.5)$ & $\begin{array}{l}0.732 \\
(0.415-1.291)\end{array}$ & 0.281 & $\begin{array}{l}0.660 \\
(0.353-1.234)\end{array}$ & 0.193 & 19 (10.9) & $\begin{array}{l}0.771 \\
(0.412-1.445)\end{array}$ & 0.418 & $\begin{array}{l}0.763 \\
(0.383-1.521)\end{array}$ & 0.443 \\
\hline \multicolumn{2}{|c|}{ CC+TC vs TT } & & $\begin{array}{l}0.893 \\
(0.630-1.266)\end{array}$ & 0.525 & $\begin{array}{l}0.976 \\
(0.662-1.439)\end{array}$ & 0.904 & & $\begin{array}{l}0.920 \\
(0.626-1.354)\end{array}$ & 0.674 & $\begin{array}{l}1.056 \\
(0.685-1.628)\end{array}$ & 0.805 \\
\hline \multicolumn{2}{|c|}{ CC vs TC+TT } & & $\begin{array}{l}0.758 \\
(0.446-1.289)\end{array}$ & 0.307 & $\begin{array}{l}0.633 \\
(0.353-1.136)\end{array}$ & 0.125 & & $\begin{array}{l}0.788 \\
(0.439-1.417)\end{array}$ & 0.427 & $\begin{array}{l}0.707 \\
(0.372-1.342)\end{array}$ & 0.288 \\
\hline T allele & 354 (62.3) & $323(65.1)$ & 1.00 (ref) & & & & $226(64.6)$ & 1.00 (ref) & & & \\
\hline$C$ allele & $214(37.7)$ & $173(34.9)$ & $\begin{array}{l}0.886 \\
(0.689-1.139)\end{array}$ & 0.344 & & & $124(35.4)$ & $\begin{array}{l}0.908 \\
(0.688-1.197)\end{array}$ & 0.493 & & \\
\hline
\end{tabular}

OR odds ratio, $\mathrm{Cl}$ confidence interval, NSCLC non-small-cell lung cancer

${ }^{a}$ Adjusted for age, gender, and smoking

Cancer (IARC) from 2008 to 2012. The data had shown that lung cancer was the first common malignancies in Chinese male (52.7 cases per 100,000 men) and the second common malignancies in Chinese female (28.4 cases per 100,000 women is just less than breast cancer). The age-standardized incidence rate (ASR) world was 45.9 per $100,000 \mathrm{~s}$ and 38.6 per $100,000 \mathrm{~s}$ for men in the USA and UK, respectively. Due to the limitations of cancer detection, lung cancer was often too late to get effective treatment. LncRNAs, one of the most important classes of ncRNAs with a length of more than 200 bp, became a hotpot as potentially critical regulators in cellular processes. The association between lncRNA DGCR5 and lung cancer had been found [31]. Many studies had shown that lncRNAs are associated with lung cancer, such as $H 19$ [32], $A T B$ [33], CDKN2B-AS1 [22], and MALAT1 [34].

$C D K N 2 B-A S 1$ is located within the CDKN2B$C D K N 2 A$ gene cluster at chromosome $9 \mathrm{p} 21$. $C D K N 2 B-A S 1$ was transcribed and sewn into a complex pattern [35] and play a role in a variety of cell functions [36]. Compared with healthy individuals, the high expression of lncRNA CDKN2B-AS1 was significantly existed in NSCLC patients [19]. In addition, the area under the curve (AUC) of $C D K N 2 B-A S 1$ was greater than tumor markers (CEA, CYFRA21-1, and SCCA). It was indicating that $C D K N 2 B-A S 1$ had a significant efficacy in distinguishing NSCLC patients and controls [19]. AUC had widely recognized as an inherent accuracy index for the authenticity evaluation of diagnostic tests. When the value of AUC is 0.5, there is no diagnostic value. When the value of AUC is 1 , the diagnostic value is high. A previous study by Nie.et al had reported that $C D K N 2 B-A S 1$ could promote the proliferation of non-small cell lung cancer cells and inhibit cell apoptosis [17].

In this study, we demonstrated that the rs 2151280 in lncRNA $C D K N 2 B-A S 1$ was significantly associated with lung cancer. The minor allele frequency (MAF) of rs2151280 was 0.268 in Chinese population. This 
Table 6 Stratified analyses of the rs2151280 with lung cancer risks and NSCLC by smoking

\begin{tabular}{|c|c|c|c|c|c|c|c|c|c|c|c|}
\hline \multicolumn{2}{|c|}{ Genotyping } & \multicolumn{2}{|c|}{ Lung cancer } & \multirow[b]{2}{*}{$P$ value } & \multirow[b]{2}{*}{ ORa $(95 \% \mathrm{Cl})$} & \multirow[b]{2}{*}{$P a$ value } & \multicolumn{2}{|c|}{ Non-small-cell lung cancer } & \multirow[b]{2}{*}{$P$ value } & \multirow[b]{2}{*}{ ORa $(95 \% \mathrm{Cl})$} & \multirow[b]{2}{*}{$P a$ value } \\
\hline & Controls (\%) & Cases (\%) & OR $(95 \% \mathrm{Cl})$ & & & & Cases (\%) & OR (95\%Cl) & & & \\
\hline \multicolumn{12}{|l|}{ Never } \\
\hline$\pi$ & $172(36.1)$ & $121(41.7)$ & 1.00 (ref) & & & & $87(39.7)$ & 1.00 (ref) & & & \\
\hline TC & $229(48.1)$ & $138(47.6)$ & $\begin{array}{l}0.857 \\
(0.626-1.173)\end{array}$ & 0.334 & $\begin{array}{l}0.865 \\
(0.624-1.201)\end{array}$ & 0.387 & $107(48.9)$ & $\begin{array}{l}0.924 \\
(0.654-1.305)\end{array}$ & 0.653 & $\begin{array}{l}0.954 \\
(0.665-1.368)\end{array}$ & 0.798 \\
\hline CC & $75(15.8)$ & $31(10.7)$ & $\begin{array}{l}0.588 \\
(0.364-0.948)\end{array}$ & 0.029 & $\begin{array}{l}0.518 \\
(0.316-0.851)\end{array}$ & 0.009 & $25(11.4)$ & $\begin{array}{l}0.659 \\
(0.391-1.109)\end{array}$ & 0.117 & $\begin{array}{l}0.572 \\
(0.334-0.980)\end{array}$ & 0.042 \\
\hline \multicolumn{2}{|c|}{ CC+TC vs TT } & & $\begin{array}{l}0.790 \\
(0.586-1.066)\end{array}$ & 0.123 & $\begin{array}{l}0.773 \\
(0.567-1.056)\end{array}$ & 0.106 & & $0.858(0.618-1.193)$ & 0.363 & $\begin{array}{l}0.850 \\
(0.604-1.197)\end{array}$ & 0.351 \\
\hline \multicolumn{2}{|c|}{ CC vs TC+TT } & & $\begin{array}{l}0.640 \\
(0.409-1.000)\end{array}$ & 0.050 & $\begin{array}{l}0.561 \\
(0.354-0.891)\end{array}$ & 0.014 & & $\begin{array}{l}0.689 \\
(0.425-1.118)\end{array}$ & 0.131 & $\begin{array}{l}0.587 \\
(0.356-0.968)\end{array}$ & 0.037 \\
\hline T allele & $573(60.2)$ & $380(65.5)$ & 1.00 (ref) & & & & $281(64.2)$ & 1.00 (ref) & & & \\
\hline$C$ allele & $379(39.8)$ & $200(34.5)$ & $\begin{array}{l}0.796 \\
(0.642-0.986)\end{array}$ & 0.037 & & & 157 (35.8) & $\begin{array}{l}0.845 \\
(0.668-1.068)\end{array}$ & 0.158 & & \\
\hline \multicolumn{12}{|l|}{ ever } \\
\hline$\pi$ & $31(47.0)$ & 86 (39.6) & 1.00 (ref) & & & & $66(37.9)$ & 1.00 (ref) & & & \\
\hline TC & $26(39.4)$ & $106(48.8)$ & $\begin{array}{l}1.470 \\
(0.812-2.661)\end{array}$ & 0.204 & $\begin{array}{l}1.477 \\
(0.762-2.862)\end{array}$ & 0.248 & $89(51.1)$ & $\begin{array}{l}1.608 \\
(0.873-2.961)\end{array}$ & 0.128 & $\begin{array}{l}1.812 \\
(0.894-3.673)\end{array}$ & 0.099 \\
\hline CC & $9(13.6)$ & $25(11.5)$ & $\begin{array}{l}1.001 \\
(0.421-2.379)\end{array}$ & 0.998 & $\begin{array}{l}0.992 \\
(0.378-2.608)\end{array}$ & 0.987 & $19(10.9)$ & $\begin{array}{l}0.992 \\
(0.403-2.440)\end{array}$ & 0.985 & $\begin{array}{l}1.025 \\
(0.366-2.872)\end{array}$ & 0.962 \\
\hline \multicolumn{2}{|c|}{$\mathrm{CC}+\mathrm{TC}$ vs TT } & & $\begin{array}{l}1.349 \\
(0.775-2.349)\end{array}$ & 0.290 & $\begin{array}{l}1.351 \\
(0.728-2.508)\end{array}$ & 0.340 & & $\begin{array}{l}1.449 \\
(0.818-2.569)\end{array}$ & 0.204 & $\begin{array}{l}1.599 \\
(0.826-3.094)\end{array}$ & 0.164 \\
\hline \multicolumn{2}{|c|}{ CC vs TC+TT } & & $\begin{array}{l}0.825 \\
(0.364-1.867)\end{array}$ & 0.644 & $\begin{array}{l}0.815 \\
(0.328-2.027)\end{array}$ & 0.660 & & $\begin{array}{l}0.776 \\
(0.332-1.815)\end{array}$ & 0.559 & $\begin{array}{l}0.756 \\
(0.287-1.987)\end{array}$ & 0.570 \\
\hline T allele & $88(66.7)$ & $278(64.1)$ & 1.00 (ref) & & & & $221(63.5)$ & 1.00 (ref) & & & \\
\hline C allele & 44 (33.3) & $156(35.9)$ & $\begin{array}{l}1.122 \\
(0.744-1.694)\end{array}$ & 0.583 & & & 127 (36.5) & $\begin{array}{l}1.149 \\
(0.753-1.754)\end{array}$ & 0.518 & & \\
\hline
\end{tabular}

OR odds ratio, $\mathrm{Cl}$ confidence interval, NSCLC non-small-cell lung cancer

${ }^{a}$ Adjusted for age, gender, and smoking

study was the first time to suggest that rs2151280 might be an important risk factor in lung cancer. Specifically, the results of our study suggested that rs2151280 CC genotype could be a protecting factor in lung cancer compared with TT genotype, especially among adenocarcinoma patients. Compared with TC/TT genotypes, CC genotype had a decreased risk of lung cancer including adenocarcinoma patients. The $\mathrm{C}$ allele had reduced the risk of NSCLC. Furthermore, in the subgroup of gender,

Table 7 Relationship of interaction between rs2151280 and smoking with lung cancer risk and NSCLC

\begin{tabular}{|c|c|c|c|c|c|c|c|c|c|c|c|c|}
\hline & \multirow[t]{2}{*}{$\begin{array}{l}\text { Controls } \\
(\%)\end{array}$} & \multirow[t]{2}{*}{ Smoking } & \multirow[b]{2}{*}{$\begin{array}{l}\text { Cases } \\
(\%)\end{array}$} & \multirow[b]{2}{*}{$\begin{array}{l}\text { OR } \\
(95 \% \mathrm{Cl})\end{array}$} & \multirow[b]{2}{*}{$P$ value } & \multirow[b]{2}{*}{$\begin{array}{l}\mathrm{OR}^{\mathrm{a}} \\
(95 \% \mathrm{Cl})\end{array}$} & \multirow[b]{2}{*}{$P^{a}$ value } & \multirow[b]{2}{*}{$\begin{array}{l}\text { Cases } \\
(\%)\end{array}$} & \multicolumn{2}{|l|}{$\begin{array}{l}\text { Non-small } \\
\text { cell lung cancer }\end{array}$} & \multirow[b]{2}{*}{$\begin{array}{l}\text { ORa } \\
(95 \% \mathrm{Cl})\end{array}$} & \multirow[b]{2}{*}{$P^{\mathrm{a}}$ value } \\
\hline & & & & & & & & & $\begin{array}{l}\text { OR } \\
(95 \% \mathrm{Cl})\end{array}$ & $P$ value & & \\
\hline CC & 75 (13.8) & Never & $31(6.1)$ & 1.00 (ref) & & & & $25(6.4)$ & 1.00 (ref) & & & \\
\hline $\mathrm{TC}+\mathrm{TT}$ & $401(74.0)$ & Never & $\begin{array}{l}259 \\
(51.1)\end{array}$ & $\begin{array}{l}1.563 \\
(1.000-2.443)\end{array}$ & 0.050 & $\begin{array}{l}1.659 \\
(1.056-2.606)\end{array}$ & 0.028 & $\begin{array}{l}194 \\
(49.4)\end{array}$ & $\begin{array}{l}1.451 \\
(0.894-2.355)\end{array}$ & 0.131 & $\begin{array}{l}1.559 \\
(0.956-2.542)\end{array}$ & 0.075 \\
\hline CC & $9(1.7)$ & Ever & $25(4.9)$ & $\begin{array}{l}6.72 \\
(2.818-16.029)\end{array}$ & $<0.001$ & $\begin{array}{l}9.392 \\
(3.849-22.914)\end{array}$ & $<0.001$ & $19(4.8)$ & $\begin{array}{l}6.333 \\
(2.541-15.784)\end{array}$ & $<0.001$ & $\begin{array}{l}8.42 \\
(3.296-21.510)\end{array}$ & $<0.001$ \\
\hline $\mathrm{TC}+\mathrm{TT}$ & $57(10.5)$ & Ever & $\begin{array}{l}192 \\
(37.9)\end{array}$ & $\begin{array}{l}8.149 \\
(4.882-13.604)\end{array}$ & $<0.001$ & $\begin{array}{l}11.442 \\
(6.626-19.761)\end{array}$ & $<0.001$ & $\begin{array}{l}155 \\
(39.4)\end{array}$ & $\begin{array}{l}8.158 \\
(4.73-14.07)\end{array}$ & $<0.001$ & $\begin{array}{l}10.905 \\
(6.100-19.495)\end{array}$ & $<0.001$ \\
\hline
\end{tabular}


Table 8 Relationship of interaction between rs2151280 and smoking with lung adenocarcinoma risk and lung squamous cell carcinoma risk

\begin{tabular}{|c|c|c|c|c|c|c|c|c|c|c|c|c|}
\hline \multirow[t]{2}{*}{ 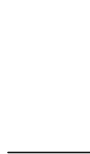 } & \multirow[t]{2}{*}{$\begin{array}{l}\text { Controls } \\
(\%)\end{array}$} & \multirow[t]{2}{*}{ Smoking } & \multicolumn{2}{|c|}{ Lung adenocarcinoma } & \multirow[b]{2}{*}{$P$ value } & \multirow[b]{2}{*}{ ORa $(95 \% \mathrm{Cl})$} & \multirow[b]{2}{*}{$p^{a}$ value } & \multicolumn{2}{|c|}{$\begin{array}{l}\text { Lung squamous cell } \\
\text { carcinoma }\end{array}$} & \multirow[b]{2}{*}{$P$ value } & \multirow[b]{2}{*}{ ORa $(95 \% C l)$} & \multirow[b]{2}{*}{$P^{a}$ value } \\
\hline & & & $\begin{array}{l}\text { Cases } \\
(\%)\end{array}$ & OR $(95 \% \mathrm{Cl})$ & & & & $\begin{array}{l}\text { Cases } \\
(\%)\end{array}$ & OR $(95 \% \mathrm{Cl})$ & & & \\
\hline CC & $75(13.8)$ & Never & $18(7.3)$ & 1.00 (ref) & & & & $6(4.8)$ & 1.00 (ref) & & & \\
\hline $\mathrm{TC}+\mathrm{TT}$ & $401(74.0)$ & Never & $\begin{array}{l}158 \\
(63.7)\end{array}$ & $\begin{array}{l}1.642 \\
(0.951-2.835)\end{array}$ & 0.075 & $\begin{array}{l}1.814 \\
(1.042-3.156)\end{array}$ & 0.035 & $\begin{array}{l}27 \\
(21.6)\end{array}$ & $\begin{array}{l}0.842 \\
(0.336-2.108)\end{array}$ & 0.713 & $\begin{array}{l}0.717 \\
(0.280-1.831)\end{array}$ & 0.486 \\
\hline CC & $9(1.7)$ & Ever & $6(2.4)$ & $\begin{array}{l}2.778 \\
(0.876-8.808)\end{array}$ & 0.083 & $\begin{array}{l}3.763 \\
(1.149-12.323)\end{array}$ & 0.029 & $11(8.8)$ & $\begin{array}{l}15.278 \\
(4.549-51.306)\end{array}$ & $\begin{array}{l}< \\
0.001\end{array}$ & $\begin{array}{l}9.537 \\
(2.716-33.490)\end{array}$ & $<0.001$ \\
\hline $\mathrm{TC}+\mathrm{TT}$ & $57(10.5)$ & Ever & $66(26.6)$ & $\begin{array}{l}4.825 \\
(2.583-9.011)\end{array}$ & 0.000 & $\begin{array}{l}7.403 \\
(3.815-14.366)\end{array}$ & $<0.001$ & $\begin{array}{l}81 \\
(64.8)\end{array}$ & $\begin{array}{l}17.763 \\
(7.237-43.600)\end{array}$ & $\begin{array}{l}< \\
0.001\end{array}$ & $\begin{array}{l}12.139 \\
(4.827-30.526)\end{array}$ & $<0.001$ \\
\hline
\end{tabular}

$O R$ odds ratio, $\mathrm{Cl}$ confidence interval

${ }^{a}$ Adjusted for age, gender, and smoking

individuals with $\mathrm{CC}$ genotype had a lower risk of lung cancer compared with individuals with TT genotype (adjusted $P=0.023$ ) in female. In female, individuals with $\mathrm{CC}$ genotype also had a lower risk of lung cancer and NSCLC compared with individuals with /TCTT genotypes (adjusted $P=0.015$ or $P=0.040$, respectively). Moreover, in the subgroup of smoking status, the same results were existed in lung cancer in never smoking population. However, we failed to find the any statistically significant association between rs2151280 and SQ. In this study, the sample size might be too small to get the significant results in SQ. The interaction of gene-environment on the risk of cancer was studied by few studies. Therefore, in this case-control study, we investigated the interaction between smoking status exposure and the $\mathrm{rs} 2151280 \mathrm{C} / \mathrm{T}$ on lung cancer risk. The crossover analysis suggested that the interaction between rs2151280 and smoking exposure on the susceptibility of lung cancer, NSCLC, AD, and SQ were existed in Chinese population. However, the quantitative analyses had shown that no any statistical significance existed on the interaction between the rs2151280 and smoking status exposure.

Admittedly, this present study had several limitations. Firstly, the cases and controls were selected from hospitals, which might lead to Berkson's bias. As such, the cases and controls selected from several different hospitals to decrease this bias. Secondly, smoking exposure data were collected by interviewing participants, which easily lead to recall bias. Thirdly, the sample size was small in the subgroup analysis and interaction analysis of this study, and the research results had certain limitations. Finally, due to the small number of genes in this study, polygenic score was not studied. In future studies, we will consider calculating the polygenic score to make our study results more meaningful. Therefore, the relationship between the rs2151280 in lncRNA CDKN2B-AS1 and lung cancer risk need to be validated by further large size studies.

\section{Conclusions}

Our findings provided new insights into the roles of rs2151280 in lung cancer risk in northern Chinese Han population. This hospital-based case-control study suggested that CDKN2B-AS1 rs2151280 T>C was associated with the risk of lung cancer. However, the gene-environment interaction between rs2151280 and smoking exposure was not statistically significant in this study.

Table 9 Interaction measures between rs2151280 in IncRNA and smoking exposure on lung cancer, NSCLC, lung adenocarcinoma, and lung squamous cell carcinoma

\begin{tabular}{|c|c|c|c|c|c|c|c|c|c|c|c|}
\hline \multirow[b]{2}{*}{ Measure } & \multirow{2}{*}{$\begin{array}{l}\text { Lung } \\
\text { cancer } \\
\text { Estimate }\end{array}$} & \multirow[b]{2}{*}{$95 \% \mathrm{Cl}$} & \multirow[b]{2}{*}{ Measure } & \multicolumn{3}{|l|}{ NSCLC } & \multicolumn{2}{|c|}{ Lung adenocarcinoma } & \multicolumn{3}{|c|}{ Lung squamous cell carcinoma } \\
\hline & & & & Estimate & $95 \% \mathrm{Cl}$ & Measure & Estimate & $95 \% \mathrm{Cl}$ & Measure & Estimate & $95 \% \mathrm{Cl}$ \\
\hline RERI & 0.866 & $-4.798-6.531$ & RERI & 1.373 & $-4.235-6.982$ & RERI & 1.405 & $-1.955-4.765$ & RERI & 2.644 & $-12.154-17.441$ \\
\hline AP & 0.106 & $-0.578-0.791$ & $\mathrm{AP}$ & 0.168 & $-0.500-0.837$ & AP & 0.291 & $-0.366-0.949$ & AP & 0.149 & $-0.663-0.960$ \\
\hline S & 1.138 & $0.469-2.760$ & $S$ & 1.237 & $0.483-3.169$ & S & 1.581 & $0.428-5.837$ & S & 1.187 & $0.428-3.293$ \\
\hline
\end{tabular}

NSCLC non-small cell lung cancer, $R E R I$ relative excess risk due to interaction, $A P$ attributable proportion due to interaction, $S$ synergy index, $95 \% C I 95 \%$ confidence interval 


\section{Abbreviations}

AD: Lung adenocarcinoma; ASR: Age-standardized incidence rate; BCC: Basal cell carcinoma; Cls: Confidence intervals; ESCC: Esophageal squamous cell carcinoma; GWASs: Genome-wide association studies; HWE: Hardy-Weinberg equilibrium; IARC: International Agency for Research on Cancer; IncRNAs: Long non-coding RNAs; MAF: Minor allele frequency; NSCLC: Nonsmall cell lung cancer; ORs: Odds ratios; PBMCs: Peripheral blood mononuclear cells; PNF: Plexiform neurofibromas; SQ: Lung squamous cell carcinoma

\section{Acknowledgements}

Not applicable.

\section{Authors' contributions}

$\mathrm{XL}$ and $\mathrm{ZY}$ contributed to the conception and design, given final approval of the version to be published. $Z C, H L$, JL, and $Z Y$ contributed to the data analyses. YB, MG, ZZ, SW, and BZ tested the statistical methods. All authors read and approved the final manuscript.

\section{Funding}

This research was funded by the National Natural Science Foundation of China (No. 81673261) and Science Foundation of School of Public Health, China Medical University.

\section{Availability of data and materials}

Not applicable.

\section{Ethics approval and consent to participate}

Written informed consent was obtained from the patients.

Ethics approval is approved by the Institutional Review Board of China Medical University.

\section{Competing interests}

The authors declare that they have no competing interests.

\section{Author details}

'Department of Epidemiology, School of Public Health, China Medical University, Shenyang 110122, People's Republic of China. ${ }^{2}$ Key Laboratory of Cancer Etiology and Intervention, University of Liaoning Province, Shenyang 110122, People's Republic of China. ${ }^{3}$ School of Nursing, China Medical University, Shenyang 110122, People's Republic of China.

\section{Received: 31 March 2019 Accepted: 1 October 2019}

\section{Published online: 27 November 2019}

\section{References}

1. Friis $\mathrm{K}$, Larsen FB, Nielsen $\mathrm{CV}$, et al. Social inequality in cancer survivors health behaviours-a Danish population-based study. Eur J Cancer Care. 2018;27(3):e12840.

2. North CM, Christiani DC. Women and lung cancer: what is new? Semin Thorac Cardiovasc Surgery. 2013;25(2):87-94.

3. Singh A, Kamal R, Ahamed I, et al. PAH exposure-associated lung cancer: an updated meta-analysis. Occup Med. 2018;68(4):255-61.

4. Tamura A, Funakoshi M, J-P NA, et al. Potential asbestos exposure among patients with primary lung cancer in Japan. J Occup Health. 2018;60(3):236-45

5. Yin Z, Cui Z, Guan $P$, et al. Interaction between polymorphisms in preMiRNA genes and cooking oil fume exposure on the risk of lung cancer in Chinese non-smoking female population. Plos One. 2015; 10(6):e0128572

6. Li H, LV X. Functional annotation of noncoding variants and prioritization of cancer-associated IncRNAs in lung cancer. Oncol Lett. 2016;12(1):222-30.

7. Yang Q, Xu E, Dai J, et al. A novel long noncoding RNA AK001796 acts as an oncogene and is involved in cell growth inhibition by resveratrol in lung cancer. Toxicol Appl Pharmacol. 2015:285(2):79-88.

8. Guttman M, Rinn JL. Modular regulatory principles of large non-coding RNAs. Nature. 2012:482(7385):339-46.

9. Tang J, Jiang R, Deng L, et al. Circulation long non-coding RNAs act as biomarkers for predicting tumorigenesis and metastasis in hepatocellular carcinoma. Oncotarget. 2015;6(6):4505-15.
10. Jin $B$, Jin $H, W u H B$, et al. Long non-coding RNA SNHG15 promotes CDK14 expression via miR-486 to accelerate non-small cell lung cancer cells progression and metastasis. J Cell Physiol. 2018;233(9): 7164-72.

11. Yap KL, Li S, Munoz-Cabello AM, et al. Molecular interplay of the noncoding RNA ANRIL and methylated histone $\mathrm{H3}$ lysine 27 by polycomb CBX7 in transcriptional silencing of INK4a. Mol Cell. 2010; 38(5):662-74

12. Popov N, Gil J. Epigenetic regulation of the INK4b-ARF-INK4a locus: in sickness and in health. Epigenetics. 2010;5(8):685-90.

13. Matarin $M$, Brown WM, Singleton $A$, et al. Whole genome analyses suggest ischemic stroke and heart disease share an association with polymorphisms on chromosome 9p21. Stroke. 2008:39(5):1586-9.

14. Debniak T, Gorski B, Huzarski T, et al. A common variant of CDKN2A (p16) predisposes to breast cancer. J Med Genet. 2005;42(10):763-5.

15. Murugan AK, Munirajan AK, Alzahrani AS. Long noncoding RNAs: emerging players in thyroid cancer pathogenesis. Endocr Relat Cancer. 2018;25(2):R59-r82.

16. Lan WG, Xu DH, Xu C, et al. Silencing of long non-coding RNA ANRIL inhibits the development of multidrug resistance in gastric cancer cells. Oncol Rep. 2016:36(1):263-70.

17. Nie FQ, Sun M, Yang JS, et al. Long noncoding RNA ANRIL promotes nonsmall cell lung cancer cell proliferation and inhibits apoptosis by silencing KLF2 and P21 expression. Mol Cancer Ther. 2015;14(1):268-77.

18. Gong WJ, Yin JY, Li XP, et al. Association of well-characterized lung cancer IncRNA polymorphisms with lung cancer susceptibility and platinum-based chemotherapy response. Tumour Biol. 2016;37(6):8349-58.

19. Xie $Y$, Zhang $Y$, Du L, et al. Circulating long noncoding RNA act as potential novel biomarkers for diagnosis and prognosis of non-small cell lung cancer. Mol Oncol. 2018:12:648.

20. Naemura M, Murasaki C, Inoue $Y$, et al. Long noncoding RNA ANRIL regulates proliferation of non-small cell lung cancer and cervical cancer cells. Anticancer Res. 2015;35(10):5377-82

21. Chen BJ, Wu YL, Tanaka Y, et al. Small molecules targeting c-Myc oncogene: promising anti-cancer therapeutics. Int J Biol Sci. 2014;10(10):1084-96.

22. Lu Y, Zhou $X, X u L$, et al. Long noncoding RNA ANRIL could be transactivated by c-Myc and promote tumor progression of non-small-cell lung cancer. OncoTargets Ther. 2016;9:3077-84.

23. Timofeeva MN, Hung RJ, Rafnar T, et al. Influence of common genetic variation on lung cancer risk: meta-analysis of 14900 cases and 29485 controls. Hum Mol Genet. 2012;21(22):4980-95.

24. Pasmant E, Sabbagh A, Masliah-Planchon J, et al. Role of noncoding RNA ANRIL in genesis of plexiform neurofibromas in neurofibromatosis type 1. J Natl Cancer Inst. 2011;103(22):1713-22.

25. Stacey SN, Sulem P, Masson G, et al. New common variants affecting susceptibility to basal cell carcinoma. Nat Genet. 2009;41(8):909-14.

26. Poi MJ, Li J, Sborov DW, et al. Polymorphism in ANRIL is associated with relapse in patients with multiple myeloma after autologous stem cell transplant. Mol Carcinog. 2017:56(7):1722-32.

27. Kang M, Sang Y, Gu H, et al. Long noncoding RNAs POLR2E rs3787016 C/T and HULC rs7763881 A/C polymorphisms are associated with decreased risk of esophageal cancer. Tumour Biol. 2015;36(8):6401-8.

28. Yin Z, Li H, Cui Z, et al. Polymorphisms in pre-miRNA genes and cooking oil fume exposure as well as their interaction on the risk of lung cancer in a Chinese nonsmoking female population. Onco Targets Ther. 2016:9:395-401.

29. Chen W, Zheng R, Baade PD, et al. Cancer statistics in China, 2015. CA Cancer J Clin. 2016:66(2):115-32.

30. Fu Z, Lu Z, Li Y, et al. Cancer incidence and mortality in Shandong province, 2012. Chin J Cancer Res. 2016;28(3):263-74.

31. Luo J, Zhu H, Jiang $H$, et al. The effects of aberrant expression of LncRNA DGCR5/miR-873-5p/TUSC3 in lung cancer cell progression. Cancer Med. 2018;7(7):3331-41

32. Huang Z, Lei W, Hu HB, et al. H19 promotes non-small-cell lung cancer (NSCLC) development through STAT3 signaling via sponging miR-17. J Cell Physiol. 2018:233(10):6768-76.

33. Cao Y, Luo X, Ding X, et al. LncRNA ATB promotes proliferation and metastasis in A549 cells by down-regulation of microRNA-494. J Cell Biochem. 2018;119(8):6935-42.

34. Lin Q, Guan W, Ren W, et al. MALAT1 affects ovarian cancer cell behavior and patient survival. Oncology Rep. 2018;39(6):2644-52. 
35. Burd CE, Jeck WR, Liu Y, et al. Expression of linear and novel circular forms of an INK4/ARF-associated non-coding RNA correlates with atherosclerosis risk. PLoS Genet. 2010;6(12):e1001233.

36. Chai L, Yuan Y, Chen C, et al. The role of long non-coding RNA ANRIL in the carcinogenesis of oral cancer by targeting miR-125a. Biomed Pharmacother. 2018;103:38-45.

\section{Publisher's Note}

Springer Nature remains neutral with regard to jurisdictional claims in published maps and institutional affiliations.

Ready to submit your research? Choose BMC and benefit from:

- fast, convenient online submission

- thorough peer review by experienced researchers in your field

- rapid publication on acceptance

- support for research data, including large and complex data types

- gold Open Access which fosters wider collaboration and increased citations

- maximum visibility for your research: over $100 \mathrm{M}$ website views per year

At BMC, research is always in progress.

Learn more biomedcentral.com/submissions 